\title{
Process Improvement of Waste Collection, Materials Recycling And Sustainable Manufacturing
}

Haishang Wu ( $\nabla$ hswu.academic@gmail.com )

University of Tsukuba: Tsukuba Daigaku

Keywords:

Posted Date: August 24th, 2021

DOl: https://doi.org/10.21203/rs.3.rs-750475/v1

License: (c) (1) This work is licensed under a Creative Commons Attribution 4.0 International License.

Read Full License 


\section{Abstract}

The authors have requested that this preprint be removed from Research Square. 